\title{
Sustainable Urban Farming in Sub-Saharan Africa: A Review of a Coupled Single-Loop Aquaponics System in Nigeria
}

\author{
Emmanuel O. Benjamin*, Domna Tzemi ${ }^{\star \star}$ and Daniela Subtil Fialho* \\ * Technical University of Munich (TUM), Alte Akademie 14, 85354 Freising, Germany. \\ ** Natural Resources Institute Finland (Luke), Latokartanonkaari 9, FI-00790 Helsinki, Finland.
}

\begin{abstract}
Countries in West Africa are adversely affected by climate change (erratic rainfall and rising temperature) resulting in floods, desertification, drought and sea level rise. These events are anticipated to have negative impacts on agricultural development on the continent, ultimately, contributing to food insecurity and environmental degradation. This implies that the production capacity of agrarian communities is unable to meet the food demand of the growing urban population. Can sustainable and innovative urban farming technology such as aquaponics achieve food security as well as sustainable development in countries vulnerable to climate change? This study uses inferential statistic to examine the plant growth performance in micro-scale aquaponics and specific growth rate per day (SGR) for the fish growth performance vis-à-vis conventional urban farming production. A quantitative analysis use to examine the barriers to adoption based on survey of (five) urban aquaculture practitioners in Lagos, Nigeria. Literature review was use to assess the economic feasibility of a small-scale aquaponics system in developing countries based on Net-Discounted Benefit-Cost Rate (DBCR). The results suggest that aquaponics can improve food security through fish and vegetable production and it is likely that urban farming practitioners will adopt the technology if support mechanism are in place. Aquaponics systems present a novel opportunity to promote environmental conservation as well as sustainable food production and consumption in urban areas in Western Africa if adequate financial credit and knowledge transfer is provided.
\end{abstract}

Keywords: Urban farming; aquaponics; food security; adoption; Nigeria; Africa.

Corresponding author contact details: Emmanuel O. Benjamin

Email: emmanuel.benjamin@tum.de

Tel: +498161712772 


\section{Introduction}

Climate change, land degradation and desertification are adversely affecting arable land, forest and coastal areas in urban and rural Africa (Olajide and Lawanson, 2014; Elias and Omojola 2015; Nkrumah, 2019). Extreme climatic events (flood and drought) due to climate change have increase in parts of sub-Saharan Africa in recent years (Akande et al., 2017; Amanchukwu et al., 2015). For instance, in Nigeria floods are most common due to increased durations and intensities of rainfall in the last three decades (Akande et al. 2017). Rising sea level and ocean surge in Southern Nigeria has submerged villages in Lagos and some places in the Niger Delta (Anabaraonye et al., 2019). Other events such as drought, desertification, land degradation, biodiversity loss, and pollution of freshwater resources are expected to be exacerbated in the future due to climate change. For instance, desertification and land degradation in rural areas is one of the reasons for rural-urban migration in Nigeria (Olagunju, 2015). Lagos, Nigeria, receives six thousand individuals per day (Oxford Analytica, 2017). The high level of internal migration has reinforced the process of land degradation and desertification, leading to expansion of the urban sprawl and clearance of land and vegetation to meet the housing and food demand of a growing urban dwellers (Ohwo and Abotutu, 2015). Agriculture also contributes to land degradation and climate change as the demand for food and non-food products in urban areas increases (Satterthwaite et al. 2010; Louwagie et al. 2011). To meet this increasing food demand, agricultural practices have changed significantly and induced profound alterations in traditional socio-agro ecosystems (Satterthwaite et al. 2010; Louwagie et al. 2011). Under the food production paradigm of the "green revolution", new practices e.g. new cultivars, over-fertilization, pesticides and hormones, and mechanization increased farm productivity (Welch and Graham, 1999). However, this has also contributed to environmental degradation of soil and water resources.

Conventional farming characterized by intensive agricultural practices involving heavy use of fertilizers and pesticides and land degradation has negative consequences such as poverty and food insecurity (Olsson et al., 2019).

Feeding an increasing urban population with less arable land while conserving the environment as well as mitigating and adapting to climate change can be rather challenging. Sustainable and innovative urban farming constitute a solution to food production for urban population because they have the potential to deliver fresh and 
nutritious food, conserve resource (land and water), and alleviate poverty and the environment (Aliyu \& Amadu, 2017; Mbow et al., 2019).

A prime example of such sustainable and innovative urban farming is aquaponics. Aquaponics not only broadens the prospects of urban farming but also promote efficiency in the use of nutrients, water, energy, and space (Goddek et al., 2019). Aquaponics offers a pragmatic solution to the challenge of food security for a growing global urban population (Goddek et al., 2019). Furthermore, aquaponics is an ideal embodiment of the Water-Energy-Food-Ecosystem (WEFE) nexus for developing countries. However, aquaponics is under researched in regions of the tropical belt, particularly in West Africa, a region with the highest rates urbanization, food insecurity and unemployment (UN DESA, 2019; Benjamin et al. 2020).

A pilot project titled - Sustainable Aquaponics for Nutritional and Food Security in Urban Sub-Saharan Africa (SANFU) was implemented in Lagos, Nigeria, from 2019 to 2020. This created the opportunity to research the potential of aquaponics to address food security, socioeconomics and ecological challenges confronting urban areas in West Africa.

This study aims to contribute to the debate on food security in urban areas of West Africa through a review of plant and fish growth performance in an aquaponics system compared to conventional urban farming. Furthermore, it gives an insight on stakeholder's perception on sustainable and innovative urban farming technologies. This includes analyzing the barriers to aquaponics adoption among urban aquaculture practitioners in Lagos, Nigeria. Overall, this study provides new perspectives on sustainable and innovative urban farming and adoption in urban West Africa.

\section{Background}

\subsection{A growing urban population: The road to Lagos}

The global urban population growth in sub-Saharan Africa has shaped its human development and natural landscapes over the last seventy years, particularly the rise and expansion of cities such as Lagos, Nigeria. This megacity has grown from 305,000 in 1950 to 13.463 million inhabitants in 2018, and it is projected to reach 20.6 million by 2030 (UNDESA, 2019). However, Lagos State is believe to currently have over 21 million inhabitants (FAO, 2017; Ogwu, 2019). This population growth rate is, in part, 
due to massive rural-urban migration and unprecedented economic growth, turning Lagos into Nigeria's economic hub (Elias and Omojola, 2015).

However, over 50 percent of Lagosians live below the poverty line $(\$ 1.9)$ hence are disproportionally exposed to the negative externalities of urbanization (LSG, 2013). These externalities includes malnourishment, undernutrition, limited green vegetation, informal settlements, ineffective management of waste and wastewater, inadequate access to water and sanitation. Furthermore, widespread use of generators by households and businesses due to shortage of power supply result in greenhouse gases (GHG) emissions. Thus, the city is plunged into food insecurity, poverty, environmental degradation and high levels of air pollution (LSG, 2013).

\subsubsection{The climate crisis: a further call for resilience}

Lagos, Nigeria is vulnerable to climate change. Parts of the low-lying coastal city is less than two meters above sea level (UN-HABITAT, 2011; Olajide, 2014). Climate change and the consequent sea-level rise (SLR) are very likely to exacerbate vulnerability further threatening the livelihoods of the growing urban poor population (Adelekan, 2010; UN DESA, 2019). Women and children are often the most vulnerable and bearers of the consequence i.e. malnourishment, undernutrition (Akerele, 2013; Nkrumah, 2019; Mbow et al. 2019; Matemilola and Elegbede 2017; van Wesenbeeck, 2018). The occurrence of floods also has a devastating impact on the livelihoods of the low-income communities in Lagos (Adelekan 2010; Sojobi, 2016). Flooding abruptly interrupts economic activities especially urban farming. Low-income communities and urban farmers especially aquaculturist in Lagos have experienced flooding and economic losses (Oyebola et al. 2020). Projections of regional sea level changes for low- (RCP $\left.{ }^{1} 2.6\right)$ and high-emissions scenarios (RCP 8.5) predict a SLR between 50 and 80 centimeters, respectively, by the end of the century in Lagos (Oppenheimer, 2019). Such a rise is 'very likely' to be accompanied by a higher frequency of extreme sea level (ESL) events, like storm surges and tides resulting in flooding (Magnan, 2019). Ajibade (2016) argue that a combination of SLR and a single ESL event in the low-elevation areas of Lagos could adversely affect millions of people and have catastrophic consequences for businesses and infrastructures.

\footnotetext{
${ }^{1}$ Representative Concentration Pathways are scenarios that describe alternative trajectories for carbon dioxide emissions
} 
Nevertheless, the risk of flooding in Nigeria has been primarily attributed to urban development in wetland areas (UN-HABITAT, 2011; Adelekan, 2010; Sojobi, 2016). This includes the destruction of mangroves that are natural buffers against coastal floods as well as lack of proper drainage systems (UN-HABITAT, 2011; Adelekan, 2010; Sojobi, 2016). Extended dry periods lead to evaporation, ultimately, drought, which causes plant failure and death of livestock. All this exacerbates the vulnerability of Lagosians to climate change (Olajide, 2014; Adelekan, 2010).

\subsubsection{Urban food (in)security}

Food security is aggravated by climate change. Food security refers to availability physical available; accessibility, economical and physical accessible; utilization, nutritional physiological necessities; and stability, stable and sustained over time (FAO, 2008). Food accessibility is an intricate issue for urban dwellers, as they often rely on regional and global supplies (Revi, 2014). Mbow et al. (2019) argue that the changing climatic drivers are already impacting and will continuing to impact food security, resulting in losses in yields and nutritional values of crops in tropical and sub-tropical regions. Oyebola et al. (2020) found that flooding in 2012 caused losses of 29,972 metric tons of fish (- $\mathrm{N}$ - = naira) 239.8 million in fourteen states, including Lagos, Nigeria. Likewise, small vegetable farmers have registered losses within Lagos State, attributing their low yields on the heavy rains concentrated over a shorter period of time (Aboyeji, 2015). The number of undernourished and food insecure individuals in Nigeria has been on the increase in the last ten years (Development Initiatives, 2018; Matemilola and Elegbede 2017).

Nigeria is a food-deficient nation and dependent on food imports of grains, livestock products, and fish to meet internal demand (FAO, 2019). Less than 15 percent of the food consumed in Lagos State is produced internally, while more than 50 percent of the fish consumed is imported (FAO and ECOWAS, 2017; LSG, 2013). Consumption of vegetables among low-income households in Lagos is estimated at 2.55 portions per day compared to the world average of four portions per day i.e. 200 grams (Raaijmakers et al. 2018 ). While animal protein intake in Lagos has been increasing in recent years due to consumption of poultry meat, the average daily intake is low according to international standards (FAO and ECOWAS, 2017). The estimated consumption of animal-sourced protein in 2013 was 40 percent lower than the 
recommended 34 grams per person daily (LSG, 2013). Moreover, fish consumption, an important source of omega 3 , amino acids and polyunsaturated fat, remains particularly low in Nigeria (FAO, 2017; Matemilola and Elegbede 2017).

\subsubsection{Urban farming: more than food production}

Urban framing, synonymous to urban agriculture (UA), supports the livelihoods of tens of millions of people throughout the world (Smit et al. 1996). These are farming practices 'within and surrounding the boundaries' of a city, providing food products from crops, livestock and fisheries, forestry products, non-wood forest products, and environmental services (FAO, 1999). In most cities in sub-Saharan Africa, urban farming is a common coping strategy of the poor to prevalent poverty and food insecurity, and sometimes a means to generate additional income (Nkrumah, 2019; Bisaga et al. 2019; Gray, 2020). Urban farming may boost the availability and continuous access to food, and alleviate poverty (Bisaga et al., 2019; Nkrumah, 2019; Gray et al. 2020; Junge et al. 2020). For food produced within the urban ecosystem, the urban dwellers tend to have improved access to more diverse, 'fresh and nutritious food' e.g. fruits, vegetables and fishes as well as urban greening. This also support environmental conservation and climate change mitigation and adaptation in urban areas (Mbow et al. 2019; Wahab and Popoola 2019). Smit et al. (1996) argue that urban framing is intensive in nature, which raises sustainability issues.

Individuals in Lagos undertake urban farming to complement the insufficient earning from non-farming activities (Taiwo, 2014). In the context of Lagos, built-up area expansion, population growth, limited technological innovation, environmental pollution etc. are some of the reasons for modest growth in urban farming (Taiwo, 2014; Junge et al. 2020; Specht et al. 2019). Other major obstacles for urban farming in Nigeria are related to the 'political neglect', poor investment and the lack of knowledge among farmers (Wahab and Popoola 2019). One of the pragmatic solutions to address the aforementioned shortfalls of urban farming in Lagos, Nigeria is aquaponics, whose details will be discussed in the following section.

\subsubsection{Aquaponics: a farming novelty}

Aquaponics is a combination of aquaculture and hydroponic, commonly, in a recirculating production system (FAO, 2014; Palm et al., 2018; Specht et al., 2019). 
Wastewater from the fish tanks pass through filtrations, and provides nutrients to the plants placed in growth beds, before the recycled water is returned to the fish tanks (FAO, 2014; Palm et al., 2018; Specht et al., 2019). The mechanical filter removes solid wastes and the uneaten feed from the water, then a biological filter 'processes the dissolved wastes' (FAO, 2014; Kledal \& Thorarinsdottir, 2018; Lennard \& Goddek, 2019). In the biological filter, bacteria break ammonia into nitrate, making the water rich in nitrate and other nutrients for taken by plants (e.g. vegetables or/and fruits). The cycle ends with the purification of the water returning to the fish tank (FAO, 2014; Kledal \& Thorarinsdottir, 2018; Lennard \& Goddek, 2019). Such coupled single-loop system conserves water and can be done on limited space (Benjamin et al. 2020). In addition to the coupled single-loop system, there is also the decoupled or multi-loop aquaponics system, where the water from plants does not return to the fish tanks (Lennard \& Goddek, 2019). Decoupled systems operate with a temporary recirculation of water, functioning as a 'hybrid system', or operate in 'unidirectional way', where water only flows from the fish tanks to the plant unit (Pantanella, 2018). Decoupled systems allow an increased level of independence between fish and plant components. This method offers two main advantages: it eliminates the risk of flowing toxic water into fish tanks; and offers farmers the possibility of separating the aquaculture and the hydroponic subsystems (Pantanella, 2018). Other aquaponics techniques include floating aquaponics, saline aquaponics through the integrated multi-trophic aquaculture, and open pond aquaponics (FAO, 2014; Palm et al., 2018; Pantanella, 2018; Sunny et al., 2019; ). The most common methods for plant cultivation include continuous flooding or floating raft, nutrient film technique (NFT) and flood and drain or ebb and flow (granite and clay pebbles bed) (Love et al., 2014; 2015; Benjamin et al. 2020). The most common fish species raised worldwide in aquaponics units are tilapia, catfish, and ornamental fish, while salad greens, herbs (e.g. basil and non-basil herbs), tomatoes, lettuce, kale, chard, pak choi, peppers and cucumbers are the most common crops grown (Love et al., 2014; Love et al., 2015; Benjamin et al. 2020).

(a) Fish and crop production

Raising of African catfish in aquaponics systems enables harvests within short-period intervals (Pantanella, 2018; Benjamin et al., 2020). Aquaculturist have successfully tested high fish stock densities (100 fish/m2), delivering relatively high quantity of fish (Sunny et al., 2019). Low-tech and low-cost aquaponics design with $27 \mathrm{~m}^{2}$ showed the 
ability to produce 400 grams of tilapia per day for home consumption (FAO, 2014; Pantanella, 2018). For vegetable production in aquaponics systems, low-nutrientdemand plants, e.g. leafy green vegetables and herbs, have been observed to perform well (FAO, 2014). Fruiting vegetables, botanical fruits as well as but high-nutrientdemand plants also do well in aquaponics systems but require extra care (FAO, 2014). flood and drain or ebb and flow (granite and clay pebbles bed) have shown better conditions for polyculture than continuous flooding or floating raft (FAO (2014). Although nitrogen is often adequately available in an aquaponics system (depending on fish feed), it may be deficient in other nutrients such as iron, potassium and calcium (Benjamin et al., 2020; FAO, 2014; Pantanella, 2018). However, chelated iron and organic fertilizers are available supplements (FAO, 2014; Benjamin et al., 2020).

(b) Barriers to adoption

Challenges of adoption of innovation in urban farming in Lagos, Nigeria, include illiteracy of farmers, and limited agricultural technologies (LSG, 2013). These obstacles may be attributed to the negligence of urban farming in the food debate, which seems to be gradually changing with recent initiatives that seek to increase local food supply (FAO and ECOWAS, 2017). Energy is an important input in innovative urban farming technologies such as aquaponics that determines the feasibility of operations. Energy is the second most expensive operational category in aquaponics, with the possibility of cost reduction through renewable energy and energy efficiency appliances (Tokunaga et al., 2015). The use of aquaponics for sustainable urban farming depends on the interconnectedness of various fields of expertise (Tokunaga et al., 2015; Gott et al., 2019; Junge et al., 2017). According to Dos Santos (2016), the cooperation between researchers, businesses, farmers, private sector, and decision-makers will make urban environments favorable to the establishment of aquaponics. Social enterprises can also support the establishment of aquaponics based on sustainability (social, environmental and economic) principles (Dos Santos, 2016). However, the success of an aquaponics model operated by a social enterprise depends on policies and regulations of food systems (Milliken and Stander, 2019). Furthermore, social equity approach to aquaponics requires high initial investment and maintenances costs and may result in 'concentration of ownership' by larger enterprises with easy access to capital and crowding out of smaller enterprises (Specht et al., 2019). 
(c) Technical feasibility

Small-scale aquaponics has limited social, economic and technical challenges compared with the larger and commercial aquaponics operations (Turnšek et al., 2020). An aquaponics system with a fish tank 1000 liters and a growing area of $\sim 3$ $\mathrm{m}^{2}$ is considered small-scale (FAO, 2014). However, Palm et al. (2018) argue that a coupled system with a total size less than $50 \mathrm{~m}^{2}$ can be considered small-scale. A small-scale aquaponics system can be set-up by non-experts with low investment costs. However, the coupled system technology associated with small-scale operations presents some technological limitations. Due to the coupled characteristic of these systems, practitioners are limited to biological control of pest (FAO, 2014). Beebe et al. (2020) identified technological challenges among the non-expert participants as controlling pests and bugs; fish management (overpopulation); and water quality ( $\mathrm{pH}$ and temperature). Maintaining an optimal biomass ratio and the correct feed rate ratio is critical to keep the appropriate nitrate balance of the system. Commercial and large-scale ${ }^{2}$ aquaponics system often apply decoupled systems that requires other technologies and specialized knowledge (Kledal \& Thorarinsdottir, 2018; Palm et al., 2018). However, larger and more complex aquaponics operations have higher demands for the stability of the system, resulting in high investment costs, advanced knowledge and high-energy demand (Palm et al., 2018).

\section{Materials and Methods}

This study is based on a coupled single-loop small-scale aquaponics systems. The SANFU project consist of flood and drain or ebb and flow (granite and clay pebbles bed) and continuous flooding or floating raft as well as two fish tanks on an area of 2.5 $\mathrm{m}^{2}$. Each fish tank had a volume of approximately $700-800$ liters. This aquaponics facility in a greenhouse setting, partially powered by solar energy, is a prototype for urban and rural areas in West Africa. This SANFU project showcases the sustainability attributes of aquaponics in urban farming compared to conventional urban farming (control field) (see figure 1,2 and 3). Some of the vegetables and fruits cultivated in the aquaponics system include Lagos Spinach or Soko (Celosia Argentea), African

\footnotetext{
2 Without setting a clear distinction between small-scale and semi-commercial aquaponics, Palm et al. (2018) delimits semi-commercial at an area of above 50 to $100 \mathrm{~m}^{2}$ up to four tanks; and intermediate/large-scale operations are above 100 up to $500 \mathrm{~m}^{2}$. Both can possibly use decoupled systems.
} 
eggplant or Efo Igbo (Solanum macrocarpon, Family Solanaceae), Scotch Bonnet Peppers or Atarodo (Capsicum chinence) and tomatoes (Solanum lycopersicum). Furthermore, African catfish (C.gariepinus and C. anguillaris) and Tilapia (Oreochromis nilotirus and Guineensis) were also raised (see figure 4).

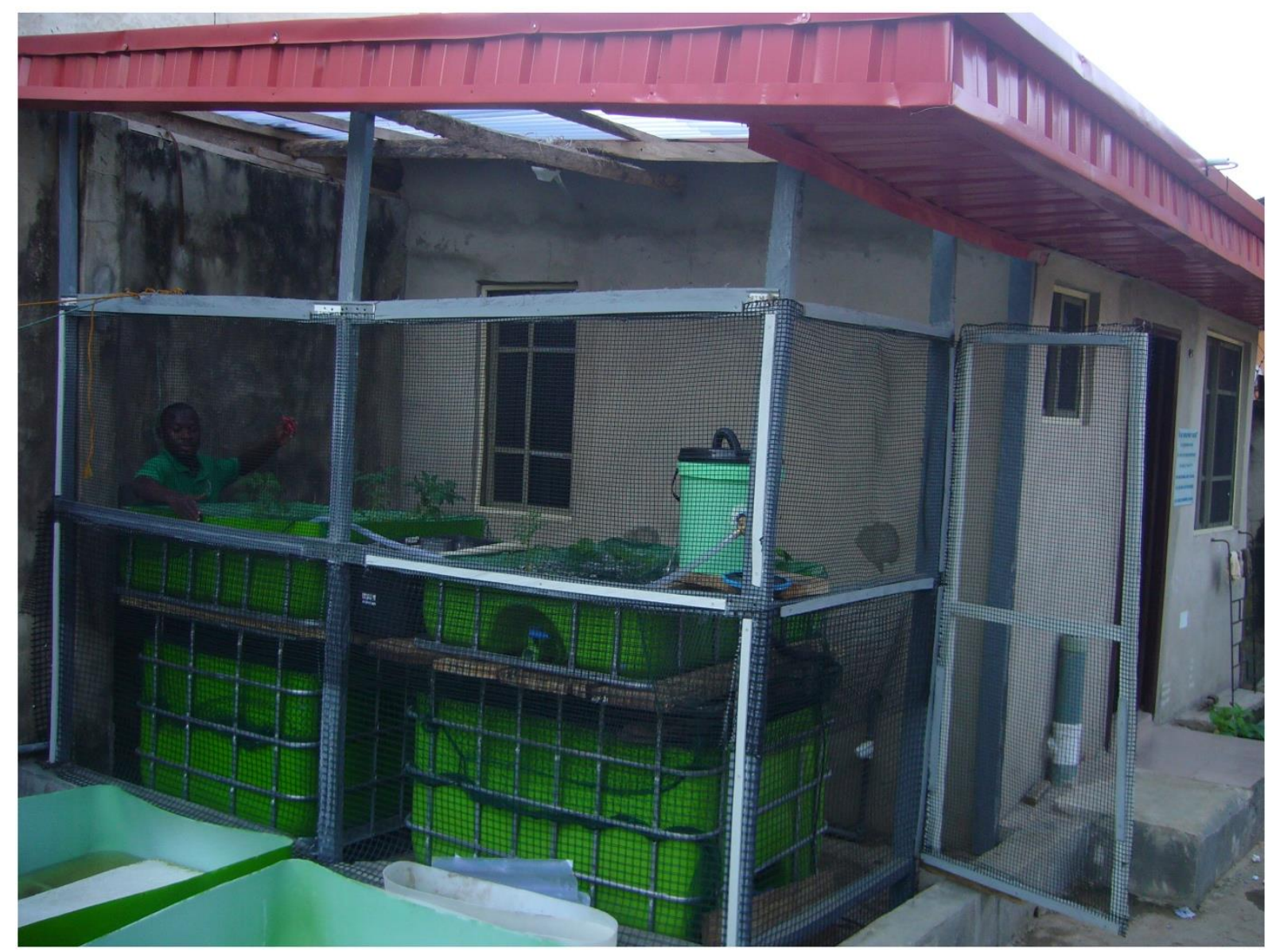

Figure 1. The SANFU demonstration site in Lagos, Nigeria 2019 - 2020

The comparative study of plant performance in the SANFU project is based on the growth measurement i.e. height of crops in the aquaponics systems as compared to crops cultivated in small urban plot, as a form of control, in the first four months. The experimental and control field was approximately $1 \mathrm{~m}^{2}$ located at the SANFU demonstration site (see figure 2 and 3 ). A t-test is conducted on the values from the experimental results. This inferential statistic was done to ascertain significant differences between the means in heights of vegetables and fruits in the aquaponics and conventional urban farming. The t-test is used for testing the hypothesis that results are comparable. The mathematical formula of the t-test $(t)$ is denoted as:

$$
t=\frac{m-\mu}{s / \sqrt{n}}
$$

where $m$ is the mean, $\mu$ the theoretical value, $S$ the standard deviation and $n$ the 
variable set size. The fish performance was also examined through the evaluation of the specific growth rate per day (SGR). The mathematical formula of SGR is denoted as:

$S G R \% d a y^{-1}=\frac{100\left(\ln W_{t}-\ln W_{0}\right)}{t}$

Where, $W_{0}$ is the initial wet weight, $W_{t}$ is final wet weight and $t$ is the number of days (Sikawa and Yakupitiyage, 2010).

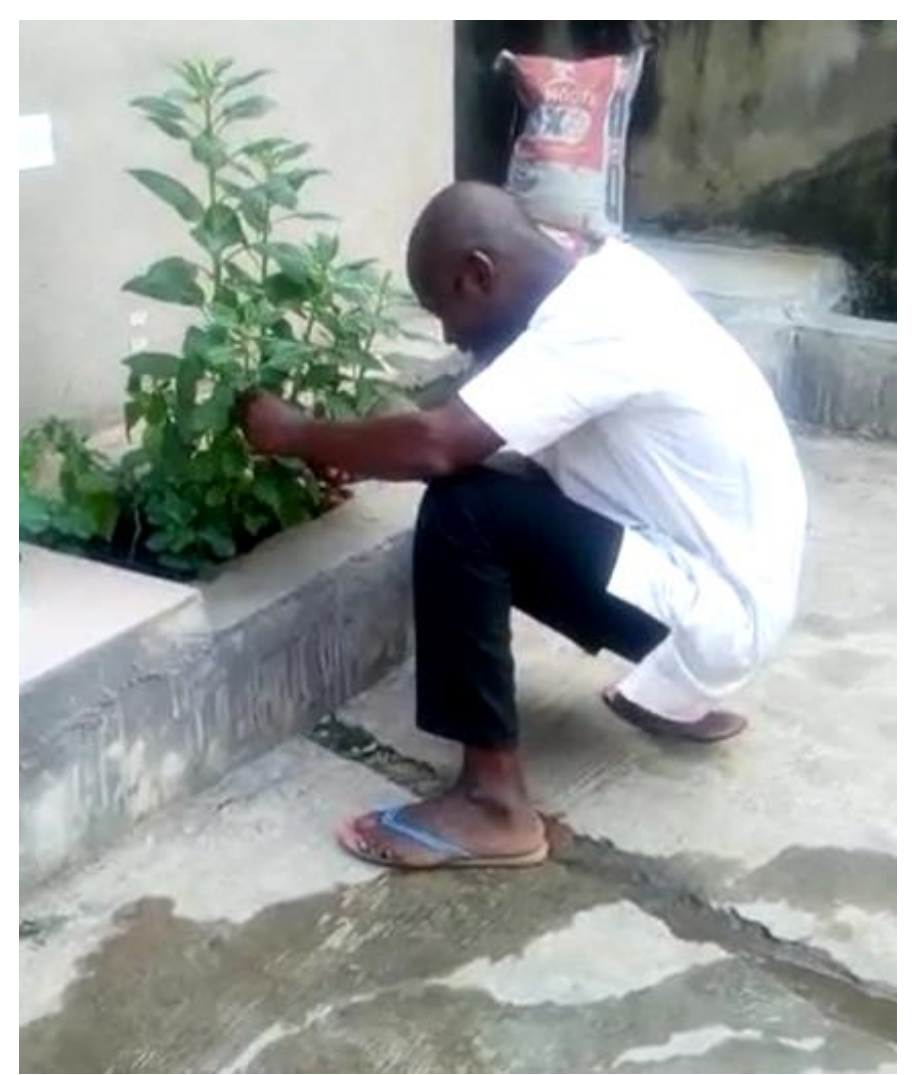

Figure 2. The control plot of the SANFU project 


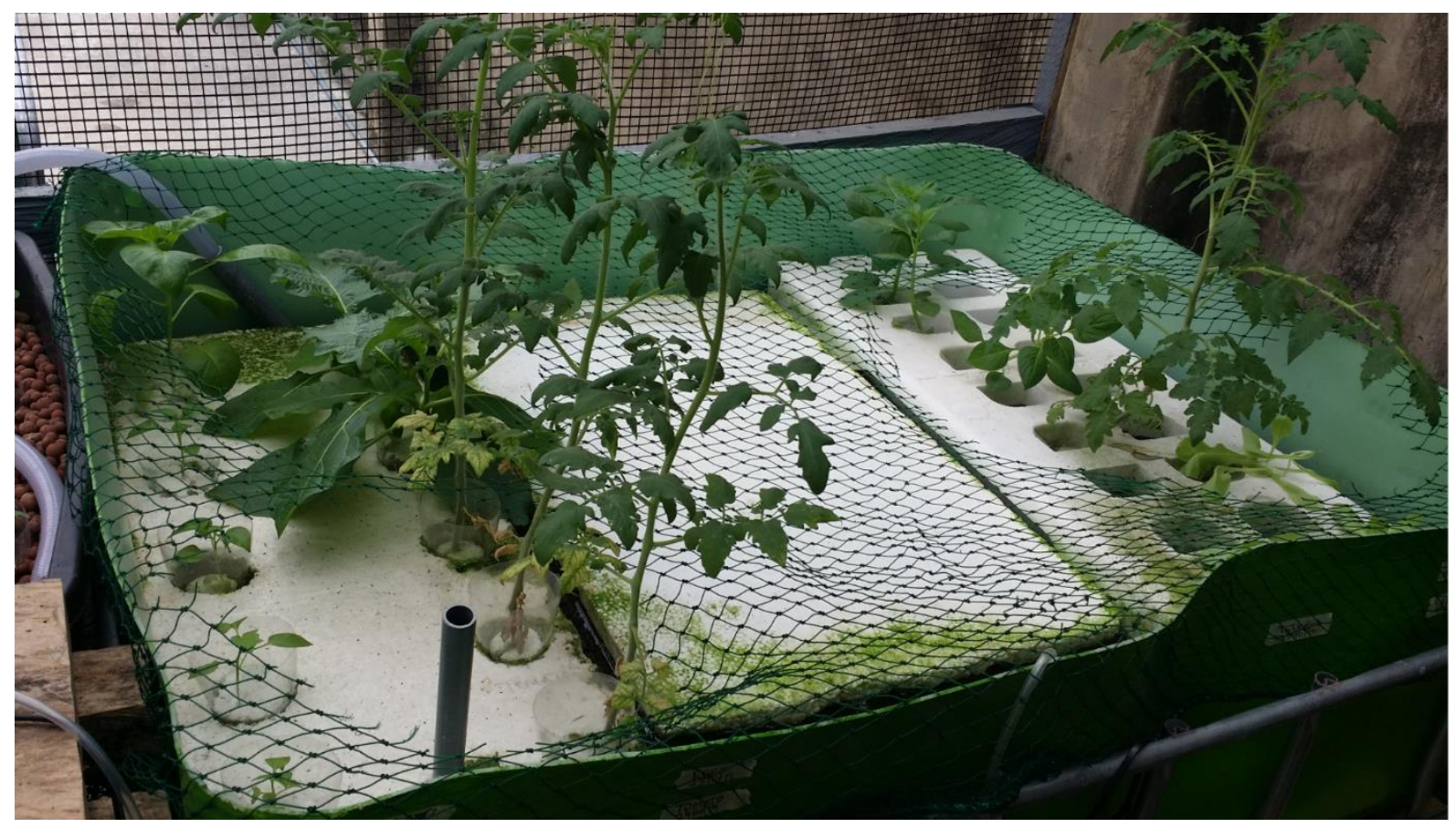

Figure 3. A cross of plant in the continuous flooding aquaponics system

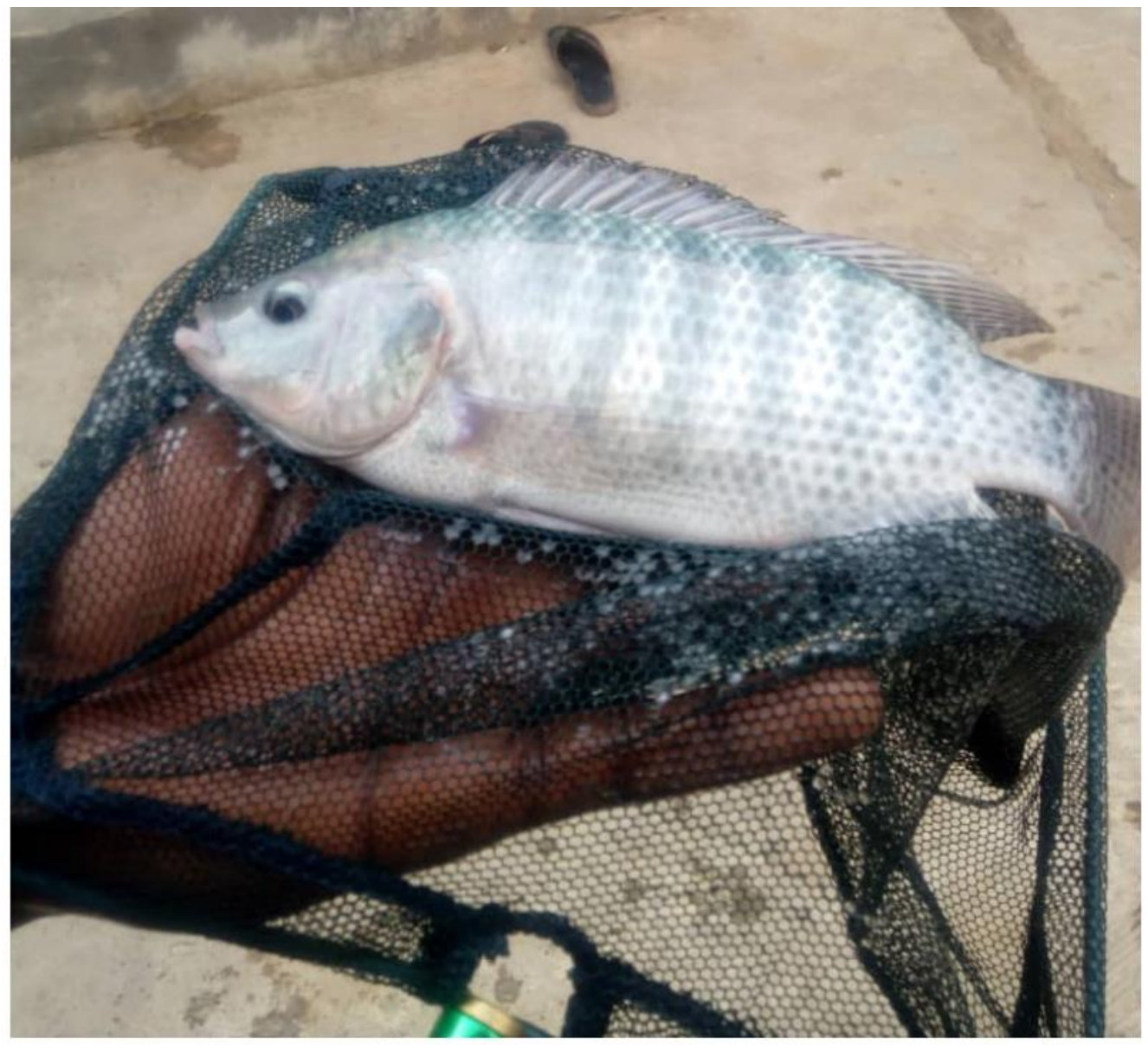

Figure 4. A Tilapia fish raised in an aquaponics system 
A questionnaire was developed and administered to urban aquaculturists. The guideline for interviews from Specht et al. (2019) was used to structure the aquaponics component of the questionnaires. The guide for survey design for the adoption of agricultural technology from CIMMYT (1993) was used to draft the general components on the farmers' profile. The selection criteria established that urban farmers, preferably from Alimosho local government area in Lagos State would be interviewed. The (proximity) requisite was based on the local government area with the highest population in Lagos and the ability of farmers to visit the SANFU project demonstration site where interviews were conducted. Given the exploratory character of this study, a non-probability sampling method was used, combining purposive and convenience sampling. The sample consist of five urban aquaculturists between the ages of 30 and 44 years old. Three of the farmers had Bachelor of Science (B.sc) degrees, while two farmers had informal agricultural-related training. Only one farmer owned the facility where the aquaculture operation was located. The years of experience among urban aquaculturists ranges between 2 and 10 years. African catfish was the common fish species produced by all respondents. The average daily hours a worker spent at the farm was between 4 hours and 10 hours with 2 paid employees. All respondents sold their unprocessed produce to market women as well as directly to final consumers. One urban aquaculturists sold processed products i.e. smoked fish. Thus, the respondents are integrated into the informal supply chain. None of the urban aquaculturists had obtained credit for their businesses. Despite being informed about government subsidies and public support programs, farmers preferred to improve their production systems through World Bank programs (two respondents) and microfinance banks (one respondent).

Benjamin et al. (2020) base the economic feasibility of solar powered aquaponics in sub-Saharan Africa on the SANFU project. Benjamin et al. (2020) conducted a Net present value analysis of foreign versus locally developed aquaponics systems in Nigeria and estimated the Net-Discounted Benefit-Cost Rate (DBCR) over a 20 years period.

\section{Results}

\subsection{Plant Growth}

The t-test of the mean height of Efo lgbo grown in the floating raft system showed a significant difference $(p=0.0145)$ after two months of cultivation compared to the Efo 
Igbo plants in the control field (fig.1.1). The mean height of Efo lgbo in the ebb and flow system was found to be significantly different $(p=0.0001)$ from the control field in the first three months of cultivation ( $\mathrm{p}=0.0275$ ) (fig.1.2). Comparing Efo Igbo grown in clay pebbles, with the control field, a significant difference $(p=0.0042)$ in the mean heights was found only in the first two months after cultivation (fig.5.1). However, after three months of cultivation, there was no significant difference in height in all grow beds compared to the control field. The results of the t-test for the comparison of Efo Igbo are also presented in Table 1.

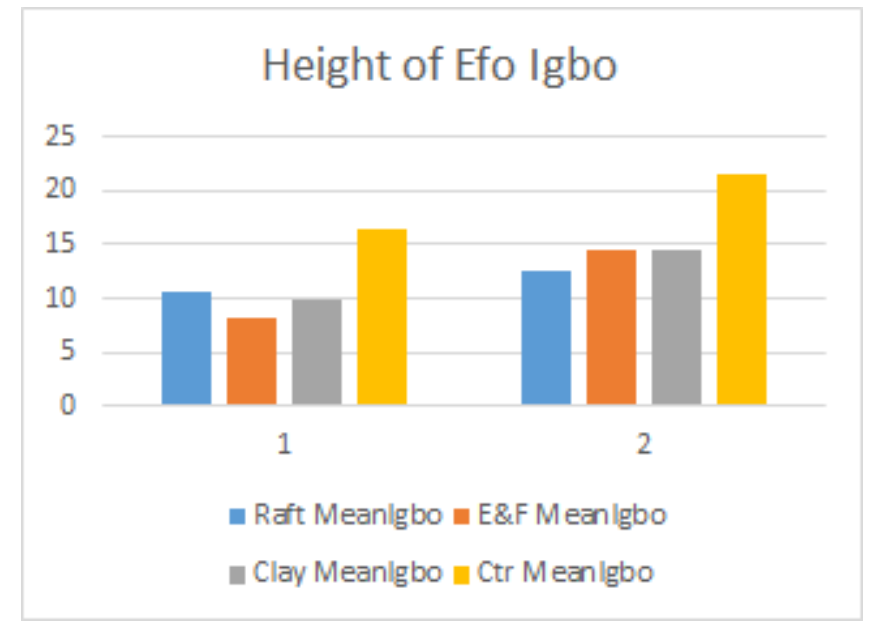

Figure 5. Mean heights (cm) of Efo lgbo (African eggplant) for aquaponics and field trials at (1) two months and (2) three months of cultivation.

Table 1. Results of two sample t-tests, where the Efo Igbo (African eggplant) height mean values of the aquaponics grow beds (CF, DF, Clay) were compared to those of the control system and the differences were statistically evaluated for $p<0.05$, after the two-sample test for variance was performed.

\begin{tabular}{|l|l|l|l|l|l|l|l|}
\hline Time & Raft & E\&F & Clay & Control & $\begin{array}{l}\text { Prob }>|t| \\
\text { Raft-Control }\end{array}$ & $\begin{array}{l}\text { Prob }>|t| \\
\text { EF-Control }\end{array}$ & $\begin{array}{l}\text { Prob }>|t| \\
\text { Clay-Control }\end{array}$ \\
\hline Month 2 & 10.55 & 8.12 & 9.87 & 16.57 & 0.014 & 0.000 & 0.004 \\
\hline Month 3 & 12.5 & 14.55 & 14.5 & 21.47 & 0.246 & 0.027 & 0.102 \\
\hline
\end{tabular}

The t-test of the mean heights for Pepper (Atarodo) showed that after two months of cultivation both ebb and flow $(p=0.0118)$ and the floating raft system $(p=0.0003)$ are significantly different from the control field (fig. 6.1). However, after three months of 
cultivation, the mean plant heights from the ebb and flow superseded that of the control field (fig. 6.2). The results of the t-test for the comparison of Pepper (Atarodo) are also presented in Table 2.

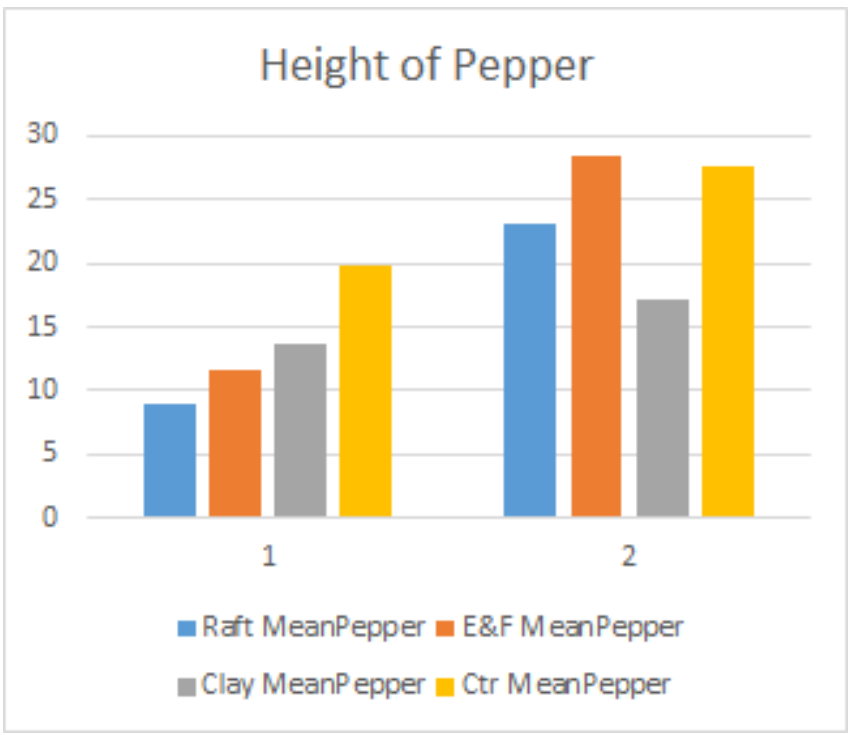

Figure 6. Mean heights of Pepper (Atarodo) plants for aquaponics and field trials at (1) two months and (2) three months of cultivation.

Table 2. Results of two sample t-tests, where the Pepper (Atarodo) height mean values of the aquaponics grow beds (CF, DF, Clay) were compared to those of the control system and the differences were statistically evaluated for $p<0.05$, after the twosample test for variance was performed.

\begin{tabular}{|l|l|l|l|l|l|l|l|}
\hline Time & Raft & E\&F & Clay & Control & $\begin{array}{l}\text { Prob }>|t| \\
\text { Raft-Control }\end{array}$ & $\begin{array}{l}\text { Prob }>|t| \\
\text { E\&F-Control }\end{array}$ & $\begin{array}{l}\text { Prob }>|t| \\
\text { Clay-Control }\end{array}$ \\
\hline Month 2 & 8.9 & 11.6 & 13.75 & 19.85 & 0.000 & 0.011 & 0.082 \\
\hline Month 3 & 23.17 & 28.5 & 17.25 & 27.7 & 0.554 & 0.904 & 0.210 \\
\hline
\end{tabular}

Tomato plants were cultivated only in the raft system and the ebb and flow with clay pebbles. The t-test showed that the mean height of the Tomato plants after two months $(p=0.0012)$ and three months $(p=0.0057)$ of cultivation in the ebb and flow with clay pebbles were significantly different from the control field (fig 7.1 and 7.2). However, no significant difference was found between raft and control systems after three months of cultivation. The results of the t-test for the comparison of Tomato are also presented in Table 3. 


\section{Height of Tomato}

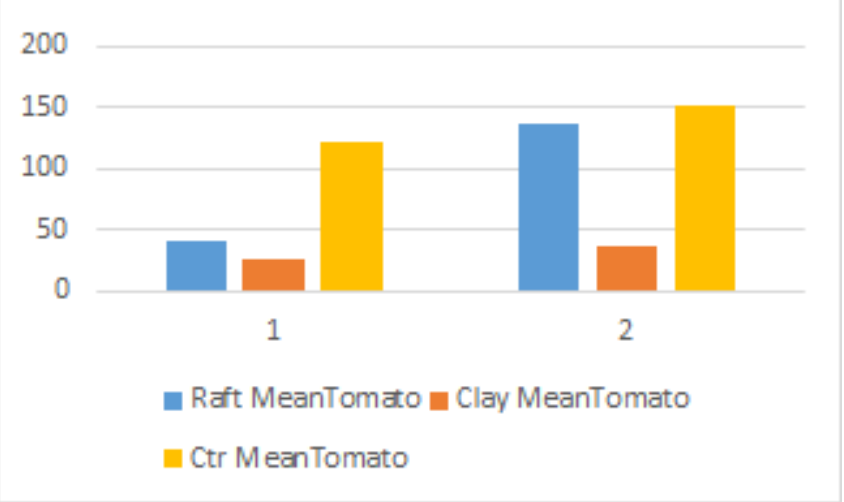

Figure 7. Mean heights of Tomato plants for aquaponics and field trials at (1) two months and (2) three months of cultivation.

Table 3. Results of two sample t-tests, where the Tomato height mean values of the aquaponics grow beds (CF, DF, Clay) were compared to those of the control system and the differences were statistically evaluated for $p<0.05$, after the two-sample test for variance was performed.

\begin{tabular}{|l|l|l|l|l|l|l|l|}
\hline Time & Raft & E\&F & Clay & Control & $\begin{array}{l}\text { Prob }>|t| \\
\text { Raft- } \\
\text { Control }\end{array}$ & $\begin{array}{l}\text { Prob }>|t| \\
\text { E\&F- } \\
\text { Control }\end{array}$ & $\begin{array}{l}\text { Prob }>|t| \\
\text { Clay- } \\
\text { Control }\end{array}$ \\
\hline $\begin{array}{l}\text { Month } \\
2\end{array}$ & 41.50 & - & 25.33 & 122.23 & 0.000 & - & 0.001 \\
\hline $\begin{array}{l}\text { Month } \\
3\end{array}$ & 136.33 & - & 37.16 & 151.33 & 0.602 & - & 0.005 \\
\hline
\end{tabular}

The examination of Lagos Spinach (Soko) showed that after two months of cultivation the mean heights in the raft system $(p=0.0473)$ as well as the ebb and flow with clay pebbles $(p=0.087)$ were significantly different from the field trials (fig.8.1). After three months of cultivation, however, none of the Lagos Spinach (Soko) plants survived the rodent attacks in the control field. Therefore, no observations were available for the second phase (fig.8.2). Results for Lagos Spinach (Soko) are presented in Table 4. 


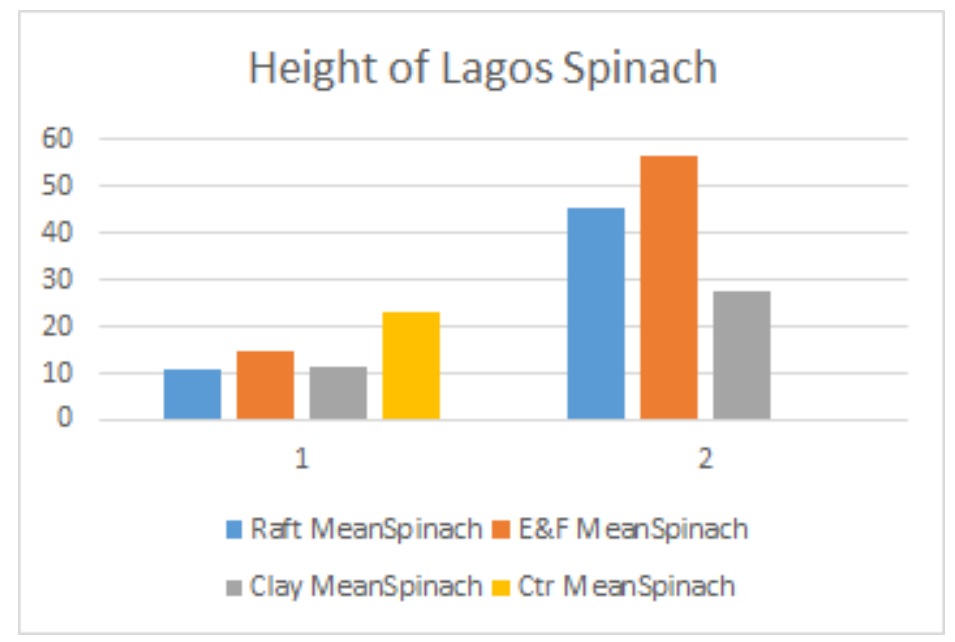

Figure 8. Mean heights of Spinach plants for aquaponics and field trials at (1) two months and (2) three months of cultivation.

Table 4. Results of two sample t-tests, where the Lagos Spinach (Soko) height mean values of the aquaponics grow beds (CF, DF, Clay) were compared to those of the control system and the differences were statistically evaluated for $p<0.05$, after the two sample test for variance was performed.

\begin{tabular}{|l|l|l|l|l|l|l|l|}
\hline Time & Raft & E\&F & Clay & Control & $\begin{array}{l}\text { Prob }>|\mathrm{t}| \\
\text { Raft- } \\
\text { Control }\end{array}$ & $\begin{array}{l}\text { Prob }>|\mathrm{t}| \\
\text { E\&F- } \\
\text { Control }\end{array}$ & $\begin{array}{l}\text { Prob }>|\mathrm{t}| \\
\text { Clay- } \\
\text { Control }\end{array}$ \\
\hline Month 2 & 10.65 & 14.46 & 11.47 & 22.825 & 0.047 & 0.216 & 0.087 \\
\hline Month 3 & 45.25 & 56.66 & 27.75 & - & - & - & - \\
\hline
\end{tabular}

\subsection{Fish growth}

The specific growth rate of Tilapia and African Catfish are analyzed and presented in Table 5 and Table 6, respectively. The $\mathrm{pH}$ measurement of the fish tanks for the duration of the SANFU project (2019 - 2020) ranged between 5.1 and 7.3 while the water temperature was between $26^{\circ} \mathrm{C}$ and $28^{\circ} \mathrm{C}$. The air stones in the fish tanks contributed to the above five parts per million (PPM) dissolved oxygen recommended for fish growth in the aquaculture system (Banerjea 1967). Results show that tilapia grew steadily over the 114 days from an individual initial weight of $59 \mathrm{~g}$ to a final mean body weight of $165 \mathrm{~g}$ and SGR ranged between 2.3\% and 1.79\% (Table 5). The SGR 
of the African Catfish showed similar results although the mean weight was much higher than that of tilapia (Table 6).

The growth performance of Tilapia and African Catfish in the aquaponics system was compared with same species grown in conventional aquaculture (Table 7). The growth rate of Tilapia and African Catfish in conventional aquaculture was retrieved from secondary sources (Goda et al. 2007; Toko et al. 2007; Fawole et. al., 2010; Terpstra, 2015; Dauda et al. 2018). The comparison of Tilapia and Africa Catfish between aquaponics and conventional aquaculture shows that in almost all stages of growth Tilapia and Africa Catfish in aquaponics performed better.

Table 5. Growth performance of Tilapia for 114 days

\begin{tabular}{|c|c|c|c|c|c|c|}
\hline Parameter & & $\begin{array}{l}\text { Fish } \\
\text { weight in } \\
\text { days } 61\end{array}$ & $\begin{array}{l}\text { Fish } \\
\text { weight in } \\
\text { days } 75\end{array}$ & $\begin{array}{l}\text { Fish } \\
\text { weight in } \\
\text { days } 89\end{array}$ & $\begin{array}{l}\text { Fish } \\
\text { weight in } \\
\text { days } 103\end{array}$ & $\begin{array}{l}\text { Fish } \\
\text { weight in } \\
\text { days } 117\end{array}$ \\
\hline $\begin{array}{l}\text { Total number } \\
\text { of fish }\end{array}$ & 6 & & & & & \\
\hline $\begin{array}{l}\text { Mean weight } \\
\text { (g fish-1) }\end{array}$ & & 59.16 & 81.66 & 97.5 & 128.33 & 165 \\
\hline $\begin{array}{l}\text { Total weight } \\
\text { (g) }\end{array}$ & 990 & & & & & \\
\hline $\begin{array}{l}\text { SGR (\%day- } \\
1 \text { ) }\end{array}$ & & & 2.30 & 1.26 & 1.96 & 1.79 \\
\hline
\end{tabular}

Table 6. Growth performance of African Catfish for 92 days

\begin{tabular}{|l|l|l|l|l|l|}
\hline Parameter & & $\begin{array}{l}\text { Fish weight } \\
\text { in days 50 }\end{array}$ & $\begin{array}{l}\text { Fish weight } \\
\text { in days 64 }\end{array}$ & $\begin{array}{l}\text { Fish weight } \\
\text { in days 78 }\end{array}$ & $\begin{array}{l}\text { Fish weight } \\
\text { in days 92 }\end{array}$ \\
\hline $\begin{array}{l}\text { Total number } \\
\text { of fish }\end{array}$ & 6 & & & & \\
\hline $\begin{array}{l}\text { Mean weight (g } \\
\text { fish-1) }\end{array}$ & & 133 & 212.5 & 270.83 & 333.33 \\
\hline $\begin{array}{l}\text { Total weight } \\
\text { (g) }\end{array}$ & 2,000 & & & 1.26 & 1.96 \\
\hline SGR (\%day-1) & & & 2.30 & & \\
\hline
\end{tabular}


Table 7. SGR comparison table of Tilapia and African Catfish between aquaponics and aquaculture

\begin{tabular}{|l|l|l|l|l|l|}
\hline Days & $\begin{array}{l}\text { SGR \% - Tilapia } \\
\text { aquaponics }\end{array}$ & $\begin{array}{l}\text { SGR \% - Tilapia } \\
\text { aquaculture }\end{array}$ & Days & $\begin{array}{l}\text { SGR \% - Catfish } \\
\text { aquaponics }\end{array}$ & $\begin{array}{l}\text { SGR \% - Catfish } \\
\text { aquaculture }\end{array}$ \\
\hline 75 & 2.30 & 2.28 & 64 & 2.3 & 1.84 (60 day) \\
\hline 89 & 1.26 & 1.92 & 78 & 1.26 & 2.07 (70 days) \\
\hline 103 & 1.96 & 1.75 & 92 & 1.96 & 1.77 (90 days) \\
\hline 117 & 1.79 & 1.49 & & & \\
\hline
\end{tabular}

\subsection{Stakeholder engagement and survey results}

Although urban aquaculturists seem to be willing to implement changes in their production systems, e.g. improvements in water usage, none of the respondents had implemented novel technology in achieving this objective. When asked about the aquaponics prototype at the SANFU demonstration site, urban aquaculturists responded positively and could envision themselves operating an aquaponics farm. The respondents identified inadequate power supply and lack of capital as the main barriers to aquaponics adoption. The advantages and disadvantages mentioned by the respondents are summed up in figure 9.

\begin{tabular}{|l|c|l|c|}
\hline Advantages & $\begin{array}{l}\text { Times } \\
\text { mentioned }\end{array}$ & Disadvantages & $\begin{array}{c}\text { Times } \\
\text { mentioned }\end{array}$ \\
\hline $\begin{array}{l}\text { Savings in water } \\
\text { usage }\end{array}$ & 3 & Financially demanding & 3 \\
\hline $\begin{array}{l}\text { Potential for large } \\
\text { scale operation }\end{array}$ & 2 & High power consumption & 2 \\
\hline $\begin{array}{l}\text { Reduction of } \\
\text { productions costs }\end{array}$ & 1 & Challenge of upscaling & 2 \\
\hline
\end{tabular}




\begin{tabular}{|l|l|l|c|}
\hline $\begin{array}{l}\text { Inexistence of bad } \\
\text { odor }\end{array}$ & 1 & Low reliability of power supply & 1 \\
\hline & $\begin{array}{l}\text { Demand in technical } \\
\text { knowledge }\end{array}$ & 1 \\
\hline & Slowdown of fish growth & 1 \\
\hline & Risks of water contamination & 1 \\
\hline
\end{tabular}

Figure 9. Advantages and disadvantages of aquaponics identified by the respondents.

To identify the determinants of aquaponics systems adoption among urban aquaculture practitioners, a number of options (see figure 10) were presented and respondents were asked to rank the level of importance.

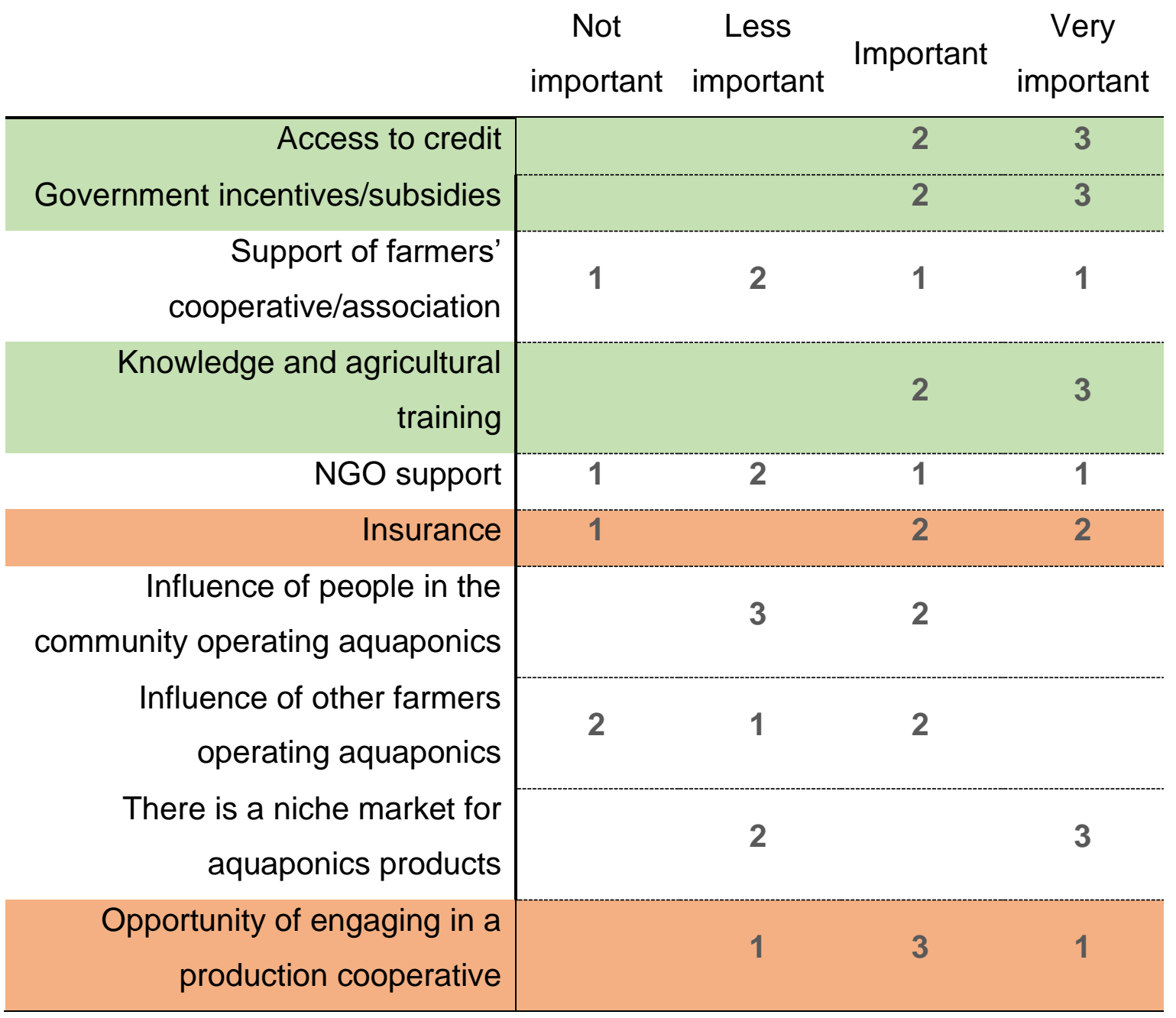

Figure 10. Variables influencing the respondents' decision on the adoption of aquaponics. 
The important set of variables in the adoption of aquaponics are highlighted in green and orange. Although less relevant for all respondents, the existence of a niche market was emphasized by urban aquaculture practitioners. To measure consumer's acceptance, the respondents were asked if their customers would buy aquaponics produce. All respondents replied affirmatively, saying that the consumers do not necessarily care about the production system as long as the output looks and tastes the same.

\subsection{Economic Feasibility}

Benjamin et al. (2020) found that the high cost of photovoltaic could reduce the economic feasibility of sustainable aquaponics in West Africa. However, profitability of aquaponics units can be attained if local materials are used for other components such as grow beds, etc. (Benjamin et al. 2020). The Net-Discounted Benefit-Cost Rate (DBCR) over a 20 years period of 1.12 reported by Benjamin et al. (2020) shows that aquaponics is a profitable form of urban food production that conserves the environment while contributing to climate mitigation and adaptation in the tropics. This is similar to the findings of Bosma et al. (2017) for aquaponics in the Philippines producing fish and vegetables in a closed-loop water system with a DBCR of 1.3. However, for Nigeria this can only be achieved if local material and labor are used to cut the high up-front cost related to aquaponics implementation (Benjamin et al. 2020).

\section{Discussion}

The result of this study shows that aquaponics can enhance food security, sustainable livelihood in urban and rural areas of West Africa. Nicholls et al. (2020) argue that urban and peri-urban farming communities in Africa could significantly contribute to food security, improvements of ecosystem services and soil conservation through innovation. In terms of crop growth in a coupled single-loop aquaponics system, the performance of ebb and flow grow beds with gravel was somewhat comparable to that of conventional farming for Peppers and Efo lgbo after a three months period. One important aspect to note is that three months after cultivation of Efo Igbo, Pepper and Lagos Spinach, no differences in growth rate between the aquaponics grow beds and the control field was observed. Palm et al (2019) argue that the use of Tilapia in 
aquaponics generally increases the yield of certain plants as compared to African Catfish given the boost effect of the former. Palm et al (2019) attributed the improved plant growth for Tilapia to the effect of light orientation and fish physiology. While the Tomato plants in the ebb and flow grow bed with clay, fertilized by African Catfish wastewater, underperformed, the growth of Tomato in the floating raft system was comparable to the control field. This may be due to a number of factors ranging from seasonal swing to fertilization challenges. The fish growth in the aquaponics system performed somewhat better compared to conventional aquaculture. Somerville et al (2014) argue that a number of fish species, among others, Tilapia and African Catfish have shown excellent growth rates in aquaponics units. Palm et al (2014) found that Tilapia growth in a coupled single-loop system aquaponics system with restricted feed input was close to optimal level but not necessarily African Catfish.

The results of this study is mostly consistent with previous work done on the performance of diverse crops in different grow beds substrates in an aquaponics system (Salam et al. 2014; Lennard and Leonard 2006; Palm et al 2019). Furthermore, extreme rodent attacks and climate events (heavy rainfall) that affected certain plants cultivated in the control field is an argument for the use of greenhouses in aquaponics in West Africa. This finding is not surprising given that a controlled environment has been proposed for the sustainable development in small and large-scale agriculture production in sub-Saharan Africa (Pack and Mehta 2012; Wayua et al. 2020; Proksch et al. 2019). Wayua et al. (2020) argue that small-scale greenhouses can enhance food production in Africa, despite challenges ranging from pests and diseases, high investment costs to lack of knowledge.

The use of a mixed energy matrix i.e. photovoltaic and on-grid for powering appliances during the SANFU project was not only environmentally friendly but compensates for the power outage often experienced in Lagos, Nigeria. Similarly, De Graaf and Goddek (2019) argue that such an energy smart hood, involving the circular connection of the Food-Water-Energy nexus, performs well for aquaponics. Conventional aquaculture often uses gasoline generators for an average of four hours a week in pumping fresh water into fish tanks, which is environmentally unfriendly and unsustainable. Compared to conventional aquaculture production, the SANFU project was able to reduce GHG emission due to mixed energy matrix or smart hood. The SANFU project was estimated to sequester approximately 489 tCO2eq per year (see Cioablă and lonel 2011). 
Several challenges peculiar to sustainable urban farming interventions (see Benjamin et al. 2018 and Benjamin 2018) such as gender bias, exclusion of vulnerable groups and limited access to credit should be addressed at this early stage of aquaponics adoption in West Africa. The responses of aquaculturists on the advantages and disadvantages of aquaponics were similar to the findings of Specht et al. (2019) for urban farming practitioners. Practitioners indicated that sustainable and efficient use of resources (land and water) makes aquaponics attractive (Specht et al., 2019). High investment and operation costs, particularly electricity, are obstacles to a profitable aquaponics enterprise (Specht et al., 2019; Love et al., 2015). The technical challenges was also a concern among respondents, with farmers linking poor water management of the system to risk of water contamination. According to Love et al. (2015), human capital is central to aquaponics operations as the success of an enterprise is strongly correlated with farmers' knowledge. A number of urban aquaculturists in our sample were highly educated. This could have significant importance for aquaponics adoption since education is positively associated with the ability to acquire new knowledge and operate with new technologies (Llewellyn and Brown, 2020). For access to market, small-scale aquaponics sell their produce through direct sales, including selling at their facility, farmer markets and roadside stands (Love et al., 2015). Since smaller production facilities are confronted with fewer regulations, direct sales may be the simplest selling strategy in dealing with the political and legal barriers (Gott et al., 2019; Specht et al. 2019; Milliken \& Stander, 2019). The sampled urban aquaculturists do not access credit due to high interest rates and stated that they had difficulties obtaining credits. Cabannes (2012) argues that, overall, there is insufficient specific funding programs for urban farming. The level of government support given to aquaculture development in Lagos, Nigeria (see Elias and Omojola, 2015), should therefore be extended to aquaponics. To promote aquaponics as an urban farming technology that tackles climate change and promotes sustainability (social ecological and economics) in sub-Saharan Africa, tenure status, education, access to market and credit are crucial factors that needs urgent attention. Furthermore, the use of local material in aquaponics systems should be emphasized. 


\section{Conclusions}

Climate change and food insecurity combined with the rapid urbanization requires urgent transition to sustainable food production systems that are climate resilient in urban areas of sub-Saharan Africa. The development of a resilient urban farming is also a chance to absorb the staggering number of young labor force migrating from rural to urban areas (Ogwu 2019). This study explores the potential of aquaponics to respond to these challenges. Aquaponics plays an important role in the provision of food to urban areas, especially in regions vulnerable to climate change. The SANFU project explores the technical, social, and economic feasibility of aquaponics for West Africa. The delivery of fresh vegetable and fish protein as well as conservation of the environment through aquaponics in West Africa have been confirmed by the outcome of the SANFU project. Thus, aquaponics contributes to food security, enhancing access to a healthy diet in Lagos, while conserving the environment. The aquaponics system has also shown great potential for all-year-round food production and comparable performances to soil-based systems.

A limited number of urban aquaculturists in Lagos, Nigeria, through stakeholder interviews and engagement, identified the opportunities and challenges of aquaponics systems in comparison to their current production systems. They envision transitioning to aquaponics and were enthusiastic about upscaling options. The sampled urban aquaculturists in Lagos, Nigeria, identified the determinants of adoption of aquaponics as access to credit, government incentives and agricultural training. Conversely, inadequate and unreliable energy supply and lack of specialized knowledge were some of the barriers to aquaponics' adoption. Planning urban spaces to accommodate novel urban farming such as aquaponics is equally crucial. To promote aquaponics in Lagos and West Africa, governments should assist farmers in accessing and planning land use, technical training, marketing, business management, and finance.

\section{Acknowledgments}

This study recognizes the support of Fiat Panis Foundation, Germany, Aglobe Development Center, Nigeria (www.aglobedc.org) and Technical University of Munich, Germany, in the implementation of the SANFU project. A special thanks to Mr. Sulaimon Babalola for conducting the interviews and Mr. Dare Balogun. 


\section{Funding}

This study received financial support from the Fiat Panis Foundation, Germany. We would also like to thank the following individuals for their financial support: Mrs. Abiola Benjamin, Mrs. Bunmi Benjamin-Saliu, Ms. Ebun Benjamin, Mrs. Gabriele LohreyBenjamin, Ms. Funmi Amu, Mr. Mohamed Ouedraogo, Mr. Oreoluwa Ola, Mr. Ti Amu (Blackhall Wells Systems Group LLC, Fort Worth, Texas), Mr. Tosin Adeleye and Mr. Yomi Salako.

\section{References}

Aboyeji, K. (2015). Heavy rainfall threatening crops, livelihoods of Nigerian farmers. Earth Journalism Network. Retrieved from https://earthjournalism.net/stories/heavy-rainfall-threatening-crops-livelihoodsof-nigerian-farmers

Adelekan, I. O. (2010). Vulnerability of poor urban coastal communities to flooding in Lagos, Nigeria. Environment and Urbanization, 22(2), 433-450. doi:10.1177/0956247810380141

Ajibade, I., McBean, G., \& Bezner-Kerr, R. (2013). Urban flooding in Lagos, Nigeria: Patterns of vulnerability and resilience among women. Global Environmental Change, 23(6), 1714-1725. doi:https://doi.org/10.1016/j.gloenvcha.2013.08.009

Ajibade, I., Pelling, M., Agboola, J., \& Garschagen, M. (2016). Sustainability Transitions: Exploring Risk Management and the Future of Adaptation in the Megacity of Lagos. Journal of Extreme Events, 03(03), 1650009. doi:10.1142/s2345737616500093

Akande, A. et al., (2017). Geospatial Analysis of Extreme Weather Events in Nigeria (1985-2015) Using Self-Organizing Maps. Advances in Meteorology. https://doi.org/10.1155/2017/8576150

Akerele, D., Momoh, S., Aromolaran, A. B., Oguntona, C. R. B., \& Shittu, A. M. (2013). Food insecurity and coping strategies in South-West Nigeria. Food Security, 5(3), 407-414. doi:10.1007/s12571-013-0264-x

Aliyu, A. A., \& Amadu, L. (2017). Urbanization, cities, and health: The challenges to Nigeria - A review. Annals of African medicine, 16(4), 149-158. doi:10.4103/aam.aam_1_17 
Amanchukwu, R. N. et al. (2015). Climate change education in Nigeria: The role of curriculum review. Education, 5(3): 71-79

Anabaraonye, B. et al. (2019). Educating farmers and fishermen in rural areas in Nigeria on climate change mitigation and adaptation for global sustainability. International Journal of Scientific \& Engineering Research, 10(4),1391-1398

Banerjea, S. M. (1967). Water quality and soil condition of fish ponds in some states of India in relation to fish production. Indian journal of Fisheries, $14(1 \& 2), 115$ 144.

Beebe, J. K., Amshoff, Y., Ho-Lastimosa, I., Moayedi, G., Bradley, A. L. C., Kim, I. N., ... Chung-Do, J. J. (2020). Reconnecting Rural Native Hawaiian Families to Food through Aquaponics. Genealogy, 4(1). doi:10.3390/genealogy4010009

Benjamin, E. O., Ola, O., \& Buchenrieder, G. (2018). Does an agroforestry scheme with payment for ecosystem services (PES) economically empower women in sub-Saharan Africa?. Ecosystem Services, 31, 1-11.

Benjamin, E. O. (2018). Financial institutions and trends in sustainable agriculture: Synergy in rural sub-Saharan Africa (Doctoral dissertation, Universität Wuppertal, Fakultät für Wirtschaftswissenschaft/Schumpeter School of Business and Economics» Dissertationen).

Benjamin, E. O., Buchenrieder, G. R., \& Sauer, J. (2020). Economics of small-scale aquaponics system in West Africa: A SANFU case study. Aquaculture Economics \& Management, 1-17. doi:10.1080/13657305.2020.1793823

Bisaga, I., Parikh, P., \& Loggia, C. (2019). Challenges and Opportunities for Sustainable Urban Farming in South African Low-Income Settlements: A Case Study in Durban. Sustainability, 11(20). doi:10.3390/su11205660

Bosma, R. H., Lacambra, L., Landstra, Y., Perini, C., Poulie, J., Schwaner, M. J., \& Yin, Y. (2017). The financial feasibility of producing fish and vegetables through aquaponics. Aquacultural Engineering, 78, 146-154. https://doi.org/10.1016/j.aquaeng.2017.07.002.

Cabannes, Y. (2012). Financing urban agriculture. Environment and Urbanization, 24(2), 665-683. doi:10.1177/0956247812456126

CIMMYT Economics Program. (1993). The Adoption of Agricultural Technology: A Guide for Survey Design. Mexico, D.F.: CIMMYT.

Cioablă A. E. \& lonel, I. (2011). Biomass waste as a renewable source of biogas production-experiments. In M. Manzanera (Ed) Alternative Fuel, InTech. 
Dauda, A. B., Romano, N., Chen, W. W., Natrah, I., \& Kamarudin, M. S. (2018). Differences in feeding habits influence the growth performance and feeding efficiencies of African catfish (Clarias gariepinus) and lemon fin barb hybrid (Hypsibarbus wetmorei $\hat{\gamma} \times$ Barboides gonionotus + ) in a glycerol-based biofloc technology system versus a recirculating system. Aquacultural Engineering, 82, 31-37.

De Graaf, F., \& Goddek, S. (2019). Smarthoods: Aquaponics Integrated Microgrids. In Aquaponics Food Production Systems (pp. 379-392). Springer, Cham.

Development Initiatives (2018). Global Nutrition Report - Country Profile: Nigeria.

Dos Santos, M. J. P. L. (2016). Smart cities and urban areas-Aquaponics as innovative urban agriculture. Urban Forestry \& Urban Greening, 20, 402-406. doi:10.1016/j.ufug.2016.10.004

Elias, P., \& Omojola, A. (2015). Case study: The challenges of climate change for Lagos, Nigeria. Current Opinion in Environmental Sustainability, 13, 74-78. doi:10.1016/j.cosust.2015.02.008

FAO. (1999). Urban and peri-urban agriculture. Paper presented at the Comittee on Agriculture, Rome.

FAO. (2008). An Introduction to the Basic Concepts of Food Security.

FAO. (2014). Small-scale aquaponics food production - integrated fish and plant farming. FAO fisheries and aquaculture technical paper, 589.

FAO, \& ECOWAS. (2017). Urban Food Systems, Food Security and Nutrition in West Africa: Lagos, Nigeria.

FAO. (2019). Nigeria at a glance. Retrieved from http://www.fao.org/nigeria/fao-innigeria/nigeria-at-a-glance/en/

Fawole, F. J., Adeoye, A. A., Tiamiyu, L. O., Ajala, K. I., Obadara, S. O., \& Ganiyu, I. O. (2020). Substituting fishmeal with Hermetia illucens in the diets of African catfish (Clarias gariepinus): Effects on growth, nutrient utilization, haematophysiological response, and oxidative stress biomarker. Aquaculture, 518, 734849.

Goda, A. M., El-Haroun, E. R., \& Kabir Chowdhury, M. A. (2007). Effect of totally or partially replacing fish meal by alternative protein sources on growth of African catfish Clarias gariepinus (Burchell, 1822) reared in concrete tanks. Aquaculture Research, 38(3), 279-287 
Goddek, S., Joyce, A., Kotzen, B., \& Dos-Santos, M. (2019). Aquaponics and Global Food Challenges. In S. Goddek, A. Joyce, B. Kotzen, \& G. M. Burnell (Eds.), Aquaponics Food Production Systems: Combined Aquaculture and Hydroponic Production Technologies for the Future (pp. 3-17). Cham: Springer International Publishing.

Gott, J., Morgenstern, R., \& Turnšek, M. (2019). Aquaponics for the Anthropocene: Towards a 'Sustainability First' Agenda. In S. Goddek, A. Joyce, B. Kotzen, \& G. M. Burnell (Eds.), Aquaponics Food Production Systems: Combined Aquaculture and Hydroponic Production Technologies for the Future (pp. 393432). Cham: Springer International Publishing.

Gray, L., Elgert, L., \& WinklerPrins, A. (2020). Theorizing urban agriculture: northsouth convergence. Agriculture and Human Values. doi:10.1007/s10460-02010015-x

Junge, R., König, B., Villarroel, M., Komives, T., \& Jijakli, M. (2017). Strategic Points in Aquaponics. Water, 9(3). doi:10.3390/w9030182

Junge, R., Monsees, H., Alencikiene, G., Peticila, A., Chrysargyris, A., Tzortzakis, N., . . Skar, S. L. G. (2020). Urban agriculture as a keystone contribution towards securing sustainable and healthy development for cities in the future. BlueGreen Systems, 2(1), 1-27. doi:10.2166/bgs.2019.931

Kledal, P. R., \& Thorarinsdottir, R. (2018). Aquaponics: A Commercial Niche for Sustainable Modern Aquaculture. In F. I. Hai, C. Visvanathan, \& R. Boopathy (Eds.), Sustainable Aquaculture (pp. 173-190). Cham: Springer International Publishing.

Lennard, W., \& Goddek, S. (2019). Aquaponics: The Basics. In S. Goddek, A. Joyce, B. Kotzen, \& G. M. Burnell (Eds.), Aquaponics Food Production Systems: Combined Aquaculture and Hydroponic Production Technologies for the Future (pp. 113-143). Cham: Springer International Publishing.

Lennard, W.A. and Leonard, B.V (2006) A comparison of three different hydroponic sub-systems (gravel bed, floating and nutrient film technique) in an aquaponic test system. Aquac Int 14(6):539-550. https://doi.org/10.1007/s10499-0069053-2

Llewellyn, R. S., \& Brown, B. (2020). Predicting Adoption of Innovations by Farmers: What is Different in Smallholder Agriculture? Applied Economic Perspectives and Policy, 42(1), 100-112. doi:10.1002/aepp.13012 
Louwagie, G., Gay, S. H., Sammeth, F., \& Ratinger, T. (2011). The potential of European Union policies to address soil degradation in agriculture. Land degradation \& development, 22(1), 5-17.

Love, D. C., Fry, J. P., Genello, L., Hill, E. S., Frederick, J. A., Li, X., \& Semmens, K. (2014). An international survey of aquaponics practitioners. PLoS One, 9(7), e102662. doi:10.1371/journal.pone.0102662

Love, D. C., Fry, J. P., Li, X., Hill, E. S., Genello, L., Semmens, K., \& Thompson, R. E. (2015). Commercial aquaponics production and profitability: Findings from an international survey. $\quad$ Aquaculture, 435, 67-74. doi:10.1016/j.aquaculture.2014.09.023

LSG. (2013). Lagos State Development Plan 2012-2025. Retrieved from Lagos: https://www.proshareng.com/admin/upload/report/11627-271150413proshare.pdf

Magnan, A. K., M. Garschagen, J.-P. Gattuso, J.E. Hay, N. Hilmi, E. Holland, F. Isla, G. Ko nas, I.J. Losada, J. Petzold, B. Ratter, T.Schuur, T. Tabe, and R. van de Wal,. (2019). Cross-Chapter Box 9: Integrative Cross-Chapter Box on Low-lying Islands and Coasts. In P. Zhai, M. Tignor, E. Poloczanska, K. Mintenbeck, A. Alegría, M. Nicolai, A. Okem, J. Petzold, B. Rama, \& N. M. Weyer (Eds.), IPCC Special Report on the Ocean and Cryosphere in a Changing Climate In Press.

Matemilola, S., \& Elegbede, I. (2017). The Challenges of Food Security in Nigeria. OALib, 04(12), 1-22. doi:10.4236/oalib.1104185

Mbow, C., Rosenzweig, C., Barioni, L. G., Benton, T. G., Herrero, M., Krishnapillai, M., . . Xu, Y. (2019). Food Security. In P. R. Shukla, J. Skea, E. C. Buendia, V. Masson-Delmotte, H.-O. Pörtner, D. C. Roberts, \& R. S. P. Zhai, S. Connors, R. van Diemen, M. Ferrat, E. Haughey, S. Luz, S. Neogi, M. Pathak, J. Petzold, J. Portugal Pereira, P. Vyas, E. Huntley, K. Kissick, M. Belkacemi, J. Malley (Eds.), Land: an IPCC special report on climate change, deserti cation, land degradation, sustainable land management, food security, and greenhouse gas fluxes in terrestrial ecosystems In press.

Milliken, S., \& Stander, H. (2019). Aquaponics and Social Enterprise. In S. Goddek, A. Joyce, B. Kotzen, \& G. M. Burnell (Eds.), Aquaponics Food Production Systems: Combined Aquaculture and Hydroponic Production Technologies for the Future (pp. 607-619). Cham: Springer International Publishing. 
Nicholls, E., Ely, A., Birkin, L., Basu, P., \& Goulson, D. (2020). The contribution of small-scale food production in urban areas to the sustainable development goals: A review and case study. Sustainability Science, 1-15.

Nkrumah, B. (2019). Beyond Climate Change Adaptation in Urban Africa: A Synthesis of Urban Food (In)Security. In P. B. Cobbinah \& M. Addaney (Eds.), The Geography of Climate Change Adaptation in Urban Africa (pp. 305-328). Cham: Springer International Publishing.

Odudu, C. O. (2014). Tapping the Entrepreneurial Ability of Urban Crop Farmers in Income Generation in Lagos, Nigeria. American Journal of Environmental Engineering, 4(6), 155-161. doi:10.5923/j.ajee.20140406.03

Ogwu, M. C. (2019). Towards Sustainable Development in Africa: The Challenge of Urbanization and Climate Change Adaptation. In P. B. Cobbinah \& M. Addaney (Eds.), The Geography of Climate Change Adaptation in Urban Africa (pp. 2955). Cham: Springer International Publishing.

Ohwo, O., \& Abotutu, A. (2015). Environmental Impact of Urbanization in Nigeria. British Journal of Applied Science \& Technology, 9, 212-221. Doi:10.9734/BJAST/2015/18148

Olagunju, T. E. (2015). Drought, desertification and the Nigerian environment: A review. Journal of Ecology and the Natural Environment, Vol. 7[7], pp. 196-209, July, 2015. Doi:10.5897/JENE2015

Olajide, O., \& Lawanson, T. (2014). Climate change and livelihood vulnerabilities of low-income coastal communities in Lagos, Nigeria. International Journal of Urban Sustainable Development, 6(1), 42-51. Doi:10.1080/19463138.2013.878348

Olsson, L., H. Barbosa, S. Bhadwal, A. Cowie, K. Delusca, D. Flores-Renteria, K. Hermans, E. Jobbagy, W. Kurz, D. Li, D.J. Sonwa, L. Stringer. (2019). Land Degradation. In Shukla, J. Skea, E. Calvo Buendia, V. Masson-Delmotte, H.O. Pörtner, D. C. Roberts, P. Zhai, R. Slade, S. Connors, R. van Diemen, M. Ferrat, E. Haughey, S. Luz, S. Neogi, M. Pathak, J. Petzold, J. Portugal Pereira, P. Vyas, E. Huntley, K. Kissick, M. Belkacemi, J. Malley, (eds.), Climate Change and Land: an IPCC special report on climate change, desertification, land degradation, sustainable land management, food security, and greenhouse gas fluxes in terrestrial ecosystems. In press. 
Oppenheimer, M., Glavovic, B. C., Hinkel, J., Wal, R. v. d., Magnan, A. K., AbdElgawad, A., ... Sebesvari, Z. (2019). Sea Level Rise and Implications for LowLying Islands, Coasts and Communities. In H.-O. Pörtner, D. C. Roberts, V. Masson-Delmotte, P. Zhai, M. Tignor, E. Poloczanska, K. Mintenbeck, A. Alegría, M. Nicolai, A. Okem, J. Petzold, B. Rama, \& N. M. Weyer (Eds.), IPCC Special Report on the Ocean and Cryosphere in a Changing Climate. In press. Oyebola, O. O., Efitre, J., Falaye, A. E., Dada, T. M., \& Idowu, F. C. (2020). Agriculture in the Face of Climate-Mediated Flooding in Tropical Africa: Technical Innovations of Fish Farmers in Southwestern Nigeria. In W. Leal Filho (Ed.), Handbook of Climate Change Resilience (pp. 2575-2593). Cham: Springer International Publishing.

Oxford Analytica (2017). Lagos's urban development could exacerbate inequality.

Pack, M., \& Mehta, K. (2012, October). Design of affordable greenhouses for East Africa. In 2012 IEEE Global Humanitarian Technology Conference (pp. 104110). IEEE.

Palm, H. W., Bissa, K., \& Knaus, U. (2014). Significant factors affecting the economic sustainability of closed aquaponic systems. Part II: fish and plant growth. Aquaculture, Aquarium, Conservation \& Legislation, 7(3), 162-175.

Palm, H. W., Knaus, U., Appelbaum, S., Goddek, S., Strauch, S. M., Vermeulen, T., . . Kotzen, B. (2018). Towards commercial aquaponics: a review of systems, designs, scales and nomenclature. Aquaculture International, 26(3), 813-842. Doi:10.1007/s10499-018-0249-z

Palm, H. W., Knaus, U., Appelbaum, S., Strauch, S. M., \& Kotzen, B. (2019). Coupled aquaponics systems. In Aquaponics Food Production Systems (pp. 163-199). Springer, Ch

Pantanella, E. (2018). Aquaponics Production, Practices and Opportunities. In F. I. Hai, C. Visvanathan, \& R. Boopathy (Eds.), Sustainable Aquaculture (pp. 191248). Cham: Springer International Publishing.

Proksch, G., lanchenko, A., \& Kotzen, B. (2019). Aquaponics in the built environment. In Aquaponics Food Production Systems (pp. 523-558). Springer, Cham.

Raaijmakers, I., Snoek, H., Maziya-Dixon, B., \& Achterbosch, T. (2018). Drivers of Vegetable Consumption in Urban Nigeria: Food Choice Motives, Knowledge, and Self-Efficacy. Sustainability, 10(12). Doi:10.3390/su10124771 
Revi, A., Satterthwaite, D. E., Aragón-Durand, F., Corfee-Morlot, J., Kiunsi, R. B. R., Pelling, M., ... Solecki, W. (2014). Urban areas. In C. B. Field, V. R. Barros, D. J. Dokken, K. J. Mach, M. D. Mastrandrea, T. E. Bilir, M. Chatterjee, K. L. Ebi, Y. O. Estrada, R. C. Genova, B. Girma, E. S. Kissel, A. N. Levy, S. MacCracken, P. R. Mastrandrea, \& L. L. White (Eds.), Climate Change 2014: Impacts, Adaptation, and Vulnerability. Part A: Global and Sectoral Aspects. Contribution of Working Group II to the Fifth Assessment Report of the Intergovernmental Panel of Climate Change (pp. 535-612). Cambridge, United Kingdom and New York, NY, USA: Cambridge University Press.

Salam, M. A., Jahan, N., Hashem, S., \& Rana, K. M. S. (2014). Feasibility of tomato production in aquaponic system using different substrates. Progressive Agriculture, 25, 54-62.

Satterthwaite, D., McGranahan, G., \& Tacoli, C. (2010). Urbanization and its implications for food and farming. Philosophical transactions of the royal society B: biological sciences, 365(1554), 2809-2820.

Sikawa, D. C., \& Yakupitiyage, A. (2010). The hydroponic production of lettuce (Lactuca sativa L) by using hybrid catfish (Clarias macrocephalus $\times$ C. gariepinus) pond water: Potentials and constraints. Agricultural water management, 97(9), 1317-1325.

Smit, J., Cheema, G. S., Ratta, A., Nasr, J., United Nations Development, P., \& Urban Agriculture, N. (1996). Urban agriculture : food, jobs and sustainable cities. New York, N.Y.: United Nations Development Programme.

Sojobi, A. O., Balogun, II, \& Salami, A. W. (2016). Climate change in Lagos state, Nigeria: what really changed? Environ Monit Assess, 188(10), 556. Doi:10.1007/s10661-016-5549-z

Somerville, C., Cohen, M., Pantanella, E., Stankus, A., \& Lovatelli, A. (2014). Smallscale aquaponic food production: integrated fish and plant farming. FAO Fisheries and Aquaculture Technical Paper, (589), I.

Specht, K., Zoll, F., Schümann, H., Bela, J., Kachel, J., \& Robischon, M. (2019). How Will We Eat and Produce in the Cities of the Future? From Edible Insects to Vertical Farming-A Study on the Perception and Acceptability of New Approaches. Sustainability, 11(16). Doi:10.3390/su11164315

Sunny, A. R., Islam, M. M., Rahman, M., Miah, M. Y., Mostafiz, M., Islam, N., . . Keus, H. J. (2019). Cost effective aquaponics for food security and income of farming 
households in coastal Bangladesh. The Egyptian Journal of Aquatic Research, 45(1), 89-97. Doi:10.1016/j.ejar.2019.01.003

Taiwo, O. J. (2014). Determinants of peri-urban and urban agricultural locational choice 33 ehavior in Lagos, Nigeria. Land Use Policy, 39, 320-330. Doi:10.1016/j.landusepol.2014.02.003

Terpstra, A. H. (2015). Feeding and growth parameters of the tilapia (oreochromis niloticus) in the body weight range from newly hatched larvae (about 5 mgrams) to about 700 grams. Growth, 600, 800.

Toko, I., Fiogbe, E. D., Koukpode, B., \& Kestemont, P. (2007). Rearing of African catfish (Clarias gariepinus) and vundu catfish (Heterobranchus longifilis) in traditional fish ponds (whedos): Effect of stocking density on growth, production and body composition. Aquaculture, 262(1), 65-72.

Turnšek, M., Morgenstern, R., Schröter, I., Mergenthaler, M., Hüttel, S., \& Leyer, M. (2019). Commercial Aquaponics: A Long Road Ahead. In S. Goddek, A. Joyce, B. Kotzen, \& G. M. Burnell (Eds.), Aquaponics Food Production Systems: Combined Aquaculture and Hydroponic Production Technologies for the Future (pp. 453-485). Cham: Springer International Publishing.

Turnšek, M., Joly, A., Thorarinsdottir, R., \& Junge, R. (2020). Challenges of Commercial Aquaponics in Europe: Beyond the Hype. Water, 12(1). Doi:10.3390/w12010306

UN-HABITAT. (2011). Cities and Climate Change - Global Report on Human Settlements.

United Nations, Department of Economic and Social Affairs, Population Division - UN DESA. (2019). World Urbanization Prospects: The 2018 Revision (ST/ESA/SER.A/420). New York: United Nations.

van Wesenbeeck, C. F. A. (2018). Disentangling Urban and Rural Food Security in West Africa. West African Papers, 15.

Wahab, B., \& Popoola, A. (2019). Urban Farmers' Perceptions and Adaptation Strategies to Climate Variability in Ibadan, Nigeria. In P. B. Cobbinah \& M. Addaney (Eds.), The Geography of Climate Change Adaptation in Urban Africa (pp. 123-154). Cham: Springer International Publishing.

Wayua, F. O., Ochieng, V., Kirigua, V., \& Wasilwa, L. (2020). Challenges in greenhouse crop production by smallholder farmers in Kisii County, Kenya. African Journal of Agricultural Research, 16(10), 1411-1419. 
Welch, R. M., \& Graham, R. D. (1999). A new paradigm for world agriculture: meeting human needs: productive, sustainable, nutritious. Field crops research, 60(1-2), $1-1$ 